\title{
Dissemination and Popularization of Improved Technology through Front Line Demonstrations among Sesame Farmers of Bundelkhand Region
}

\author{
Shiv Ratan", Shobharam Thakur, M. K. Nayak and V. K. Singh \\ AICRP on Sesame, JNKVV-College of Agriculture, Tikamgarh, India \\ *Corresponding author
}

\section{A B S T R A C T}

\begin{tabular}{|l|}
\hline Key w o r d s \\
Front Line \\
Demonstrations, \\
Sesame Farmers \\
\hline Article Info \\
\hline $\begin{array}{l}\text { Accepted: } \\
\text { 12 December } 2020 \\
\text { Available Online: } \\
\text { 10 January } 2021\end{array}$ \\
\hline
\end{tabular}

\section{Introduction}

India is largest importer of edible oils as its per capita consumption/year is $19.0 \mathrm{~kg}$ which is about $36 \%$ higher than standards for normal health. Due to the substantial gap between demand and availability of edible oil, India imported 15.01 MT which incurred Rs. 66680 crores foreign currency load in 2018-19. (Commodity Profile of Edible Oils for Sept. 2019)

Present uncertain climatic scenario reduces the options of farmers to choose comparatively better input responding crops in low rainfall tracts having poor to medium fertility soils. Under such situation, farmers have limited option for kharif crop. Sesame is the best option in unpredictable current scenario of climate.

Sesame (Sesamum indicum L.) also known as Til is one of the oldest important oilseed crop of India grown in semi-arid tropics, subtropics and temperate regions covered 15.97 lakh ha. with the productivity of $473 \mathrm{~kg} / \mathrm{ha}$ in 2019 (Annual Report of AICRP on sesame \& niger, 2019-20). Sesame oil has long self life due to higher linoleic content which increases resistance to oxidation and rancidity. Seed is rich source of Vitamin $\mathrm{E}, \mathrm{A}, \mathrm{B} 1, \mathrm{~B} 2$, niacin, minerals and methionine amino acid hence used for domestic as well as pharmaceutical industries. 
It is widely preferred for its qualities of high drought tolerance during the vegetative stage mainly attributed to its extensive root system. In India, sesame is grown in Kharif, rabi and summer season or more than one season in some states. It is mainly grown in Uttar Pradesh, Rajasthan, Madhya Pradesh, West Bengal, Andhra Pradesh, Maharashtra, Gujarat, Tamil Nadu, Odisha and Karnataka.

This study is intended to disseminate and popularize improved production technology and create awareness among farmers that how modern production technologies can be helpful to increase income under uncertain climate which is regular feature of Bundelkhand region. Such efforts will change the mindset of farmers towards innovative production technologies.

\section{Materials and Methods}

In total, 70 demonstrations were conducted under rainfed conditions by AICRP on Sesame, Tikamgarh district at farmers' field to create awareness among Bundelkhand's farmers towards modern production technologies for their own benefit during kharif 2017, 2018 and 2019. Each demonstration was planted in 0.4 ha area with whole package/improved technology along with farmers practice (FP).

Further, whole package/ improved technology comprised of HY variety, fertilizers dose, weedicide and insecticides (Table 1). The data had been collected from both improved technology and farmers practice plots. Extension gap, Technology gap, Technology index and Cost- benefit ratio were calculated with the following formulae-

Extension gap $\left(\mathrm{qha}^{-1}\right)=($ Yield of Improved technology plot $\left(\mathrm{qha}^{-1}\right)$ - Yield of Farmers practice $\left(\mathrm{qha}^{-1}\right)$

Technological gap $\left(\left(\mathrm{qha}^{-1}\right)\right)=$ Potential $\operatorname{yield}\left(\mathrm{qha}^{-1}\right)-$ demonstration yield $\left(\mathrm{qha}^{-1}\right)$

Technology index $(\%)=$ Technology gap $x$ 100 / Potential yield

Additional returns (Rs.) =Demonstration returns (Rs.) -Farmers practice returns (Rs.)

Effective gain $($ Rs. $)=$ Additional returns (Rs.) - Additional cost (Rs.)

Incremental $\mathrm{B}: \mathrm{C}$ ratio $=$ Additional returns (Rs.) / Additional cost (Rs.)

\section{Results and Discussion}

The results of this study indicate the substantially higher yields $(626 \mathrm{~kg} / \mathrm{ha})$ were recorded under Improved Technology (IT) which was more than double to the mean yield harvested under farmers practice (FP) indicating the poor adoption of innovative technologies by farmers. Hence, concentrated efforts are required to change mindset of farmers towards Improved Technology. (Table -2) Although, highest yield was harnessed in 2018 under both IT and its corresponding FP which may be effect of rainfall pattern and edaphic conditions. Results of this finding is also in agreement with Kushwaha et al., (2018) and Meena and Dudi (2018).

Extension Gap: The mean Extension Gap (EG) over years was recorded as $333 \mathrm{~kg} / \mathrm{ha}$ which is almost equal to mean yield under farmers practice (FP). This indicates poor infiltration of Improved Technology (IT) among farmers and holistic approaches would be required for speedy narrow drown this gap. Above findings are in accordance with Shiv Ratan et al., (2020). These demonstrations in one of the most effective way to change the perception of farmers towards Improved Technology (IT). In addition to this, recurrent training and field visits may change the mindset of farmers. (Dayananad et al., 2012; Katare et al., 2011; Mitra and Samajdar, 2010). 
Table.1 Components of whole package or Improved Technology of FLDs

\begin{tabular}{|l|l|l|}
\hline S.No. & Technological Interventions for Whole package/ Improved Technology \\
\hline 1 & HY Varieties & TKG-306 \& TKG-308 \\
\hline 2 & Seed rate & $2.0 \mathrm{~kg}$ \\
\hline 3 & Seed treatment & Carbendazim @3g/kg seed \\
\hline 4 & Fertilizers & $60 \mathrm{~N}: 40 \mathrm{P}: 20 \mathrm{~K}$ \\
\hline 5 & Weedicide & Quizolofop-N- ethyl (Turga Super) \\
\hline 6 & Pesticide (Need based) & Imidacloprid and/or Profenophos \\
\hline
\end{tabular}

Table.2 General details, seed yield and other parameters for gap analyses of FLD on sesame

\begin{tabular}{|c|c|c|c|c|c|c|c|c|c|}
\hline \multirow[t]{2}{*}{$\begin{array}{l}\text { S. } \\
\text { No }\end{array}$} & \multirow[t]{2}{*}{ Year } & \multirow[t]{2}{*}{$\begin{array}{c}\text { Number of } \\
\text { demonstrations }\end{array}$} & \multirow[t]{2}{*}{$\begin{array}{c}\text { Area } \\
\text { (ha) }\end{array}$} & & \multicolumn{2}{|c|}{$\begin{array}{c}\text { Mean Yield } \\
\text { (Kg/ha) }\end{array}$} & \multirow{2}{*}{$\begin{array}{c}\text { Extension } \\
\text { gap } \\
\text { (kg/ha) }\end{array}$} & \multirow[t]{2}{*}{$\begin{array}{l}\text { Technology } \\
\text { gap (kg/ha) }\end{array}$} & \multirow[t]{2}{*}{$\begin{array}{c}\text { Technology } \\
\text { index }(\%)\end{array}$} \\
\hline & & & & & IT & FP & & & \\
\hline 1 & 2017 & 40 & 16 & & 613 & 299 & 314 & 187 & 23.4 \\
\hline 2 & 2018 & 15 & 06 & & 639 & 291 & 348 & 161 & 20.12 \\
\hline 3 & 2019 & 15 & 06 & & 627 & 291 & 336 & 173 & 21.63 \\
\hline \multicolumn{2}{|c|}{ Total } & 70 & 28 & Mean & 626.4 & 294 & 332.66 & 173.66 & 21.71 \\
\hline
\end{tabular}

Table.3 Analysis of various economic parameters under IT as well as FP

\begin{tabular}{|c|c|c|c|c|c|c|c|c|c|c|c|}
\hline \multirow[t]{2}{*}{ Year } & \multicolumn{2}{|c|}{$\begin{array}{l}\text { Cost of } \\
\text { Cultivation } \\
\text { (Rs. /ha) }\end{array}$} & \multicolumn{2}{|c|}{$\begin{array}{l}\text { Mean Gross } \\
\text { return (Rs) }\end{array}$} & \multicolumn{2}{|c|}{$\begin{array}{l}\text { Net return } \\
\text { (Rs/ha) }\end{array}$} & \multicolumn{2}{|c|}{ B:C ratio } & \multirow{2}{*}{$\begin{array}{l}\text { Addition } \\
\text { al Cost } \\
\text { under IT } \\
\text { (Rs. /ha) }\end{array}$} & \multirow{2}{*}{$\begin{array}{l}\text { Addition } \\
\text { al gross } \\
\text { return } \\
\text { (Rs./ ha) }\end{array}$} & \multirow[t]{2}{*}{$\begin{array}{l}\text { Additional net } \\
\text { return (Rs./ } \\
\text { ha) }\end{array}$} \\
\hline & IT & FP & IT & FP & IT & FP & IT & FP & & & \\
\hline 2017 & 19934 & 11504 & 49500 & 21600 & 29566 & 10096 & 2.76 & 2.34 & 8430 & 27900 & 19470 \\
\hline 2018 & 21483 & 11610 & 57480 & 26190 & 36956 & 14580 & 2.8 & 2.30 & 9873 & 31290 & 22376 \\
\hline 2019 & 21025 & 11710 & 56400 & 26190 & 35378 & 14547 & 2.68 & 2.24 & 9315 & 30210 & 20831.6 \\
\hline Mean & 20814 & 11608 & 54460 & 24660 & 33967 & 13075 & 2.75 & 2.29 & 9206 & 29800 & 20893 \\
\hline
\end{tabular}

Where IT=Improved technology; FP=Farmers practice; EG=Extension gap; TG= Technology gap; TI=Technology index

Technology Gap (TG): The average TG was found $174 \mathrm{~kg} / \mathrm{ha}$ during three years investigation period. Rain fed condition, precipitation pattern, marginal and sub marginal soils may be the probable reason for this gap (Meena and Singh 2017 and Singh SB, 2017).

Technological Index (TI): TI shows the feasibility of Improved Technology at field which will be more desirable if value will be low. The average TI was accrued as $21.7 \%$ indicating the need of rigorous efforts to fast replicate Improved Technology at farmers' fields. Findings of the current study is in accordance with Arvind kumar, (2017), Balai et al., (2012); Iqbal et al., (2017), Rao et al., (2011) and Shiv Ratan et al., (2020).

For economic parameters, cost of cultivation for IT and FP were calculated (Table 3) as per prevailing prices of inputs used and outputs. The cost of cultivation under IT ranged from Rs. 19934 to 21483 with average of Rs. 20814 while same was ranged from Rs 11504 to Rs. 11710 with average of Rs. 11608 under FP. The average additional cost under IT was Rs.9206 which clearly indicated the poor 
adoption of IT in Bundelkhand. Therefore, need of hour is to intensify efforts through FLDs, trainings and personal visits to change the mindset of farmers towards improved technologies and scientific interventions.

Mean net return over study years was recorded Rs. 33967 under IT while it was Rs. 13074 under FP which show huge difference in additional net return of Rs. 20893. It is clearly indicates that farmers would have earned $62 \%$ more net income if they had adopted IT.

Further, average B: $\mathrm{C}$ ratios were 2.75 under IT and 2.29 under FP which is due to high quantum of produce harnessed under IT (Sharma et al., 2017, Meena and Singh, 2017 and Shiv Ratan et al., 2020 )

\section{References}

Arvind Kumar, Yadav DK and Rana DS. 2012. Rapeseed-mustard in India: Present scenario, future projection and R\&D issues. Indian Farming 62(8):1421.

Annual Report of AICRP on Sesame \& Niger, 2019-20.

Balai C. M, Meena R. P, Meena B. L and Bairwa RK. 2012. Impact of front line demonstration on rapeseed-mustard yield improvement. Indian Res. J. Ext. Edu., 12:113-116.

Commodity Profile of Edible Oils for Sept. 2019

Dayanand, Verma RK and Mehta, SM. 2012. Boosting mustard production Technology through front line demonstrations. Indian Res. J. Ext. Edu.,12:121-123.

https//www.nmoop.gov.in

Iqbal AM, Shikari AB, Naseer S, Nagoor S, Aziz M, Dar Z, Ali J, Ganai MA and Parry GA. 2017. Participatory varietal selection in rapeseed-mustard. J Oilseed
Brassica 8: 201-206

Katare S, Pandey SK. and Mustafa, Mohd., 2011. Yield gap analysis of rapeseed mustard through frontline demonstrations. Agriculture updates 6(2):5-7.

Kushwaha Raj Singh, Kumar Rupender, Kaur Arvinder, Bhadouria VS and Gupta Naresh. 2018. Impact of front line demonstration (FLD) on the yield of rapeseed-mustard in Gwalior district of MP. Technofame 7(1) 61-64.

Meena ML and Dudi Aishwarya. 2018. Boosting the mustard production technology through front line demonstration in Pali district of Rajasthan. Journal of oilseed brassica 9(2):176-181

Mitra B and Samjadar, T. 2010. Yield gap analysis of rapeseed and mustard through frontline demonstration. Agril. Ext Rev 22: 16-17

Meena ML and Singh D. 2017. Technological and extension yield gaps in green gram in Pali district of Rajasthan. Legume Res 40: 187-191.

Rao DM, Chandrashekhar P and Neeraiah R. 2011. Productivity enhancement in ground nut. Indian Farming 60:39-40.

Sharma R, Bhati, DS and Sharma, SK. 2017. Impact of front line demonstration on rapeseed-mustard growers. Journal of progressive Agriculture 8(1): 115-118.

Shiv Ratan, Tiwari UK, Nayak M K and Shobharam Thakur, 2020. Assessment of relative impact of improved technology and scientific interventions on the income of sesame farmers in tribal area of Bundelkhand region. Int. J. Curr. Microbiol.App. Sci., 9(7):809-813. Singh, SB. 2017. Yield gap analysis of rapeseed mustard through front line demonstration under rainfed conditions in Uttarakhand. Technofame 6(1): 8992. 


\section{How to cite this article:}

Shiv Ratan, Shobharam Thakur, M. K. Nayak and Singh, V. K. 2021. Dissemination and Popularization of Improved Technology through Front Line Demonstrations among Sesame Farmers of Bundelkhand Region. Int.J.Curr.Microbiol.App.Sci. 10(01): 2097-2101. doi: https://doi.org/10.20546/ijcmas.2021.1001.241 